Actes du 15e colloque du GERAS

\title{
Cross-cultural conflicts in ESP
}

\section{David Thomas}

\section{OpenEdition}

\author{
Journals
}

Electronic version

URL: http://journals.openedition.org/asp/4098

DOI: 10.4000/asp.4098

ISSN: 2108-6354

\section{Publisher}

Groupe d'étude et de recherche en anglais de spécialité

\section{Printed version}

Date of publication: 1 December 1994

Number of pages: 223-229

ISSN: $1246-8185$

\section{Electronic reference}

David Thomas, «Cross-cultural conflicts in ESP », ASp [Online], 5-6 | 1994, Online since 19 December 2013, connection on 01 May 2019. URL : http://journals.openedition.org/asp/4098 ; DOI : 10.4000/ asp.4098

This text was automatically generated on 1 May 2019.

Tous droits réservés 


\title{
Cross-cultural conflicts in ESP
}

\author{
David Thomas
}

1 Given the theme Culture and ESP, my first thought was to try to find a link between the two concepts, based on my personal teaching experience. After some thought, I came to the conclusion that it is not so much culture itself which is a source of problems as the conflict between the two cultures implicit in the teaching of ESP, that is to say between the British and French cultures. I teach in the Business Department of a University Institute of Technology and I have found over the years that it is quite impossible to separate what might be termed as the purely business aspect of the language from its cultural heritage. And if this were not enough of a problem in itself, the French cultural heritage of my students clashes with the content of the language I try to teach them - and not only the language, as we shall see. However, before going any further it is necessary to try and define the two concepts of ESP and Culture.

2 I thought I knew what the word "culture" meant, but I decided to look it up in various dictionaries. Here are a few of the definitions I discovered:

the total of the inherited ideas, beliefs, values and knowledge which constitute the shared bases of social action

the total range of activities and ideas of a people

a particular civilization at a particular time

the artistic and social pursuits, expression and tastes valued by a society or class

the enlightenment or refinement resulting from these pursuits

improvement by mental or physical training

ensemble des aspects intellectuels d'une civilisation

ensemble des formes acquises de comportement, dans les sociétés humaines

Having got myself rather confused with the word culture, I decided to have a go at defining ESP - at least that should be fairly simple. How wrong can one get! I consulted Pauline Robinson's ESP (1980 and Tom Hutchinson and Alan Waters' English for Specific Purposes, A learning-centered approach (1987), and came to the conclusion that there is no simple definition but rather a host of explanations of what ESP is NOT. Finally, faced with the problem of making a choice or simply glossing over the meaning, I plumped for Hutchinson and Waters' explanation that: 
ESP should properly be seen not as any particular language product but as an approach to teaching which is directed by specific and apparent reasons for learning. puzzling. Did one mean culture as applied to our profession, that is, the act of teaching, or culture as applied to the professional field our students are specialising in? In fact this expression "culture professionnelle" raised questions I had not envisaged originally. It was at this time that I began to realize just how Machiavellian the choice of this year's theme for the Colloque du GERAS really was!

6 I shall consider that the theme is the influence of culture in general on the acquisition of ESP in a specific professional context. Or, to simplify matters a little, how the underlying culture of a country, civilization, society or whatever you care to call it, influences not only the everyday language, but also the language for specific purposes, and how this in turn complicates our life as ESP teachers, since the vast majority of our students are reasonably ignorant of this culture. Hence, certain words and expressions that they are required to learn and use prove difficult for them, since these words and expressions come from the culture which lies hidden behind the language itself and about which they know very little. The result is often that they learn by rote, and thus equally often quickly forget what they have learned because they have no point of reference to which they can attach the words or expressions. However, as we shall see, words and expressions are only the tip of the iceberg since there is of course the additional difficulty of crosscultural conflicts as we have already mentioned.

7 Going back to the word culture, I tried to make a list of those many facets of our society which constitute culture. Here I fell out with one dictionary definition, since "a particular civilization at a particular time" seems to me to be somewhat incorrect given that, at any particular moment, that civilization depends on what happened before, so the definition should not really contain any temporal limits. I came up with a strictly non-exhaustive list which looks like this (see table 1).

\section{Table 1}

\begin{tabular}{|l|l|}
\hline religion & geography \\
\hline art & climate \\
\hline language & food \\
\hline history & law \\
\hline tradition & war \\
\hline behaviour & university \\
\hline mentality & trade unions \\
\hline
\end{tabular}




\begin{tabular}{|l|l|}
\hline government & industrial revolution \\
\hline and so-on, ad nauseam & \\
\hline
\end{tabular}

Having drawn up this list, the next job was to decide what to do with it. I have to confess here that I did give free rein to my imagination and tried to see what would happen if I compared the effects of each item in this list on either side of the Channel - or, if you prefer, La Manche (does anyone happen to know how the Anglo-French Tunnel came to be called the Chunnel and not the Munnel, or perhaps La Tanche? Another of the bilingual cultural mysteries of ESP, I suppose.)

In the end I decided not to go ahead with this rather extravagant exercise, partly because it is not very scientific and partly because I might have hurt some peoples' feelings, since it became obvious that one side of the Channel would inevitably prove to be superior to the other. However, I will give you just two examples before going any further.

We British are mainly Protestants, the French are largely Roman Catholics. This may explain why the French enjoy life, they can do what they like, go to confession, get rid of their heavy load of real or imagined sins and start over again. We have no such means of absolution, so we just endure life. Whilst this may sound rather flippant, I think that a little thought on the matter will show that this facet of culture goes some way at least to explaining the different mentalities between the peoples of the two nations.

11 The second concerns our two languages and the cultural impact on them. First of all we British have arguably the two greatest and most influential literary works of all time, the Bible and the Complete Works of Shakespeare. True, we have no monopoly on the Bible, but the Protestant faith lays much greater emphasis on the teaching and the learning of the Scriptures than the Roman Catholic faith does, and this naturally colours the language. Admittedly, you do have great authors, Baudelaire, Racine and Molière, to mention but a few, but none of them has had the same impact as Shakespeare. This can be explained by the fact that more people around the world speak English than French, which in turn can be explained by the fact that we were somewhat more active colonizers.

Whilst on the subject of language, it would be incorrect to gloss over two other important points, one of which is linked to what I have just said. The British have the Americans, the French have the Académie Française. Although this may sound somewhat facetious, it is in fact an important scientific point. English is a very flexible and evolving language, in fact it is evolving so fast that I, as an ESP teacher, sometimes have difficulty in keeping up with it.

Last year one of my students wrote in a paper, "I keyboarded the data." My immediate reaction was to cross it out. Subsequently I came across an article in the Journal of the British Society of Authors in which the writer said, "I cannot afford to pay someone to key-in this data". Another student came out with "We should ask the consumers associations." (You will note that there is NO apostrophe after the s of consumers!) I must confess this did upset me. A salesman or a sports car I will accept, they are the wellknown exceptions that prove the rule that in English a qualifying word cannot take an s. But "consumers associations"! It's somewhat like saying "I saw two *reds cars". Horrible, and I told him so. Whereupon, during the next lesson he produced a text taken from Newsweek in which the author had actually used the expression. In those circumstances, 
what can the poor ESP teacher do but accept defeat gracefully, and then cover himself by explaining that we are dealing with a living -and therefore evolving-language. of course, I could say that this is all the fault of the Americans, who will insist on modifying our language at the drop of a hat, just to make their life easier. But I won't. In fact, it is all our fault. Why? Because if, back in the 17th century we had not made life impossible for the Pilgrim Fathers, on religious grounds, they would have stayed where they were instead of crossing the Atlantic to set up home elsewhere. And if that had happened, today the U.S.A. could be an ex-French colony, and French the prevailing world language. So, as we can see, once again our cultural heritage is responsible for some of the problems with ESP.

The French, on the other hand, have the Académie Française. And what, you may well ask, is the significance of that? Well, whereas we allow the Americans to reinvent the English language every five minutes -we don't actually allow them to, they just do it, and we endure the consequences- the Académie Française rules over the French language with an iron fist in a steel glove, ably abetted by its Grand Inquisitor and watchdog, Bernard Pivot and his assistant, Jacques Toubon. Take two examples, the first from my own field, Business English. The word "marketing" crept quietly into the French language whereupon the Académie reacted and insisted on mercatique. The other is the word fuel, which immediately became changed to fioul (personally I wonder whether this was really necessary). And should you dare to transgress the edicts of the Académie, you will immediately be sentenced to a Pivot dictation and held up to scorn before the entire nation for every mistake, not to mention the possibility of a fine. On the other hand, should you obtain a sans-faute, you become a national hero. Small wonder that our students get confused between, on the one hand, the apparent freedom of English, and on the other, the very real rigidity of French.

From the foregoing we can see that there are two different ways of looking at culture and language. The British, who are reputed to be very conservative, are allowing their language to be changed, modified, one could go so far as to say bastardized, in the sacrosanct name of progress, whilst the French do everything possible to avoid change. At the same time, both languages conserve a certain number of cultural heritages, often in the form of sayings, expressions, quotations or allusions and these tend not to disappear from English, even if the language does evolve. Naturally, these sayings and expressions come from the near or distant past, and the more distant the past the more obscure their origins become with the passing of time. To the point where the famous English expression anon. (not to be confused with the "anon" used by Francis in the farcical tavern scene in Shakespeare's Henry IV, Pt. 1) becomes a necessary pedagogical weapon used principally in defence of the English teacher who, when faced with that rare phenomenon, (an inquisitive student who wants to know the origin of a particularly obscure expression), ripostes with "anonymous". Of course, you can't use this tactic too often without the risk of a certain loss of credibility.

At this point we may well ask ourselves another question, to what extent is Business English ESP? The problem here is inherent to the fact that whilst the ESP of, for instance, thermo-dynamics or sub-atomic particle physics deals with what might be termed hard or pure science, Business English, since its context is human contacts, can be considered as a soft science - and thus, by extension, we could perhaps talk about "soft ESP" and "hard ESP". Whilst I readily confess that I am going outside my specific field, and am therefore not really qualified to talk about it, it does seem that scientific English, in the 
pure sense of the term, has become almost codified, and therefore somewhat stultified. I am not aware whether the experts in the field would agree with me, or to what extent? If my premise is correct, this would tend to reinforce my hypothesis that Business English is soft ESP, since we are talking principally, though far from exclusively, about the spoken language, which tends to evolve faster than the written.

If we admit that Business English derives from a human science and consequently could be termed as soft ESP, then we can advance the further hypothesis that it is not the specific vocabulary which is of the greatest importance but rather the discourse and the cultural impact on its content. We then have to decide whether we are talking about culture per se or professional culture. Obviously, the links between culture in the widest sense of the word and everyday language are easy to demonstrate, such expressions as "Don't spoil the ship for a ha 'p'orth of tar", "Show him the ropes" or "The project is on the back-burner", all being worthy illustrations of this fact. We can go further and play on just one word, "scratch". Here are just a few expressions that use it;

"He didn't come up to scratch"

"You scratch my back and I'll scratch yours"

"The deal was scratched"

"They used a scratch sales team"

"He survived the business without a scratch"

"We'll have to start the campaign from scratch"

"Don't worry, I'll scratch up the money somehow"

18 I would suggest that if you gave that short list to your students and asked them what the sentences mean, you would be confronted with a lot of perplexed young people. And yet these are expressions that can be and are used in everyday Business English.

My personal feeling is that this is a minor problem compared to professional culture, which relates to the context in which the specific language is used. Here it is not so much the words and expressions themselves that form the stumbling block - although they are naturally important - as the discourse. A couple of short anecdotes can illustrate this better than any abstract explanation. Some years ago, I worked for a small firm in Paris, handling its imports. Due to go on holiday, I warned the owner of the company not to let the new manager, who could speak English, contact a certain American supplier since I was fairly sure he would put his foot in it. Sure enough, on my return I found the company in trouble. The manager in question had written to the 60-year old and rather self-important President of the American company saying, "You must let us have the goods by the 16th". Given the context, you can imagine the impact of the word "must"! The American company quite simply refused to supply the shop. Had the manager written "We would be grateful if you could deliver by the 16th because..." followed by an explanation, there would have been no problem. It took several months of pouring oil on troubled waters (there's another example, from our naval cultural heritage) to get the matter sorted out. This is but one illustration of my contention, it's not necessarily what you say, but rather the way you say it.

Another illustration of how culture, and more specifically professional culture, has an influence on ESP is the problem that I encounter all too often with commercial correspondence. French convention requires that when you write to a superior, or someone you do not know, you must start your letter with "Monsieur". This appears to be a very deeply ingrained habit, as you will see. In English, the rule is, if you know the person's name, you MUST use it, for example "Dear Mr. Jones." It doesn't matter that you have never actually met Mr. Jones, if you don't use his name, it is incorrect. Now, every 
time that I teach a new set of students how to lay out a commercial letter, I go into great detail on this point, I literally hammer this point into them. Then, as good teaching practice requires, I consolidate, I ask them all to write a letter on a given topic, in which it is obvious that they know the name of the person they are writing to.

Despite all the coaching, a good 30\% of them will write "Dear Sir"! I correct the letter with them, and when I point out that they should have used the name, they all agree, nod their heads wisely over the error of their ways and promise never to do it again. We come to the final exam, I give them a letter to write, and what happens? "Dear Sir", again! In point of fact, this is not so much the interaction of culture and ESP as a conflict between two cultures having an influence on ESP.

Another classic example is that of students who carry out training periods in companies in the UK. Not only do they have problems sorting out who is who in the hierarchical ladder, due to the very frequent use of first names, this habit can actually cause embarrassment, as the following story shows.

A couple of years ago two very good but slightly reserved female students were sent on a 2-month training period to a big British company. After a fortnight John, the Personnel Officer, and hence a very important person in the company, rang me:

"David, I think we have a problem here, the girls don't seem to like me!"

"Oh, come on, John, that's hardly likely. What's happening?"

"Well, every time I speak to them, they look elsewhere when they answer and they

never actually speak to me directly."

This was somewhat of a puzzle, as the two girls in question are very well brought-up and nice young ladies. Anyway, we agreed that I would sort it out when I arrived for my visit the following week. On arrival I took the two students into an empty office and asked them just what they had against John. They both stared at me aghast and protested that they had absolutely nothing against him, everything was fine. When asked why they never spoke to him, they both looked embarrassed and then told me. When they first arrived in the company John welcomed them and in the course of the meeting told them they were to call him John. Now he is a middle-aged, physically imposing man with a sometimes obscure sense of humour and in addition he is the Regional Personnel Manager of a company employing some 70,000 staff. The girls, who had both worked in banks in France were totally incapable of calling him by his first name! If we stop to think about this, it is tantamount to a trainee addressing a manager in a French bank using "tu" instead of "vous", and we can imagine the effect that would have! This is just another example of cross-cultural conflicts in a professional situation.

Suffice with examples, the message is quite clear, there is a very strong link between culture - or in my case professional culture - and ESP and it is further complicated by the opposition of two different cultures, which leads us back to a question I postulated at the beginning, are we talking about the professional culture of the teacher or that of the student in his/her future career. The answer now becomes quite plain, we are talking about both. We have already seen, in some detail, how that culture affects the workplace, what we have not so far considered is the teacher's role. To my mind, our job is to act as an interface between culture and ESP, or, if you prefer, to act as a guide to our students. Learning the language is one thing, divining the cultural pitfalls that are hidden by the language is quite another, and part, at least, of our job is to avoid our students falling into those traps, since the culture cannot be easily perceived if the teacher does not explain it. We have to teach them at least some of the mentality behind the language, a mentality 
which dictates how the language is used and that mentality is governed to some extent by our cultural heritage.

In other words, the three concepts are inextricably mixed. Not only do we have to teach ESP, we also have to explain how to use it and then get our students to use it properly.

Whilst I would make no pretence of having made a definitive contribution to the problem, thanks to my experience with the use of case studies and training periods abroad over the past years I can confirm that when students are put into what appears to be or is a professional situation they do try hard to remember and use what they have been taught.

\section{BIBLIOGRAPHY}

Hutchinson, Tom and Alan Waters. 1987. English for Specific Purposes, A learning-centred approach. Cambridge: Cambridge University Press.

Robinson, Pauline. 1980. ESP (English for Specific Purposes). London: Pergamon.

\section{ABSTRACTS}

The teaching of ESP necessarily has to take into account the impact of culture on language, of culture per se, as well as of specific professional culture. The British and French cultures both have an effect, one which is tempered in France by the influence of the Académie Française on the language since it tends to limit the speed at which it evolves. The very rapid current evolution of English, particularly in the sphere of Business English, is due in large part to the impact of American English. The influence of cultural heritage on what is essentially a human science leads to professional cultural conflicts which further complicate both the task of the ESP learner and that of the teacher who has to find ways to limit the effects of this conflict.

L'enseignement de l'anglais de spécialité ne peut que prendre en compte l'impact culturel sur la langue, la culture en tant que telle, la culture professionnelle spécifique. Les cultures britannique et française exercent toutes les deux une influence, tempérée, en France, par le rôle de l'Académie, qui freine l'évolution de la langue due aux changements culturels. En anglais, l'évolution est très rapide, notamment dans le domaine de la langue du commerce et des affaires, en raison, en particulier, de l'influence américaine. Ce rôle de la culture amène à des conflits culturo-professionnels qui compliquent encore davantage le travail de l'apprenant, comme du professeur, de langue de spécialité. Ce dernier se doit d'imaginer le moyen de limiter les effets de tels conflits.

\section{INDEX}

Mots-clés: culture générale, culture professionnelle, sciences humaines

Keywords: general culture, human science, professional culture 
AUTHOR

DAVID THOMAS

David Thomas enseigne à l'Institut Universitaire de Technologie de Caen, dans les départements TC et GEA. 